\title{
Triple Mediating Effect of Appearance Satisfaction, Body Image and Hope in the Relationship between Appearance Management Behavior and Happiness
}

\author{
Eun Ju Jang', Byung Soo Chang,"* \\ ${ }^{1}$ Department of Cosmetology, Graduated School, Hanseo University, Seosan Chungnam, Republic of Korea \\ ${ }^{2}$ Department of Cosmetology, Hanseo University, Seosan Chungnam, Republic of Korea
}

Received June 30, 2021; Revised September 8, 2021; Accepted October 17, 2021

\section{Cite This Paper in the following Citation Styles}

(a): [1] Eun Ju Jang, Byung Soo Chang, "Triple Mediating Effect of Appearance Satisfaction, Body Image and Hope in the Relationship between Appearance Management Behavior and Happiness, "Universal Journal of Public Health, Vol. 9, No. 5, pp. 287 - 295, 2021. DOI: 10.13189/ujph.2021.090511.

(b): Eun Ju Jang, Byung Soo Chang (2021). Triple Mediating Effect of Appearance Satisfaction, Body Image and Hope in the Relationship between Appearance Management Behavior and Happiness. Universal Journal of Public Health, 9(5), 287 - 295. DOI: 10.13189/ujph.2021.090511.

Copyright $\bigcirc 2021$ by authors, all rights reserved. Authors agree that this article remains permanently open access under the terms of the Creative Commons Attribution License 4.0 International License

\begin{abstract}
The purpose of this study is to verify the triple mediating effect of appearance satisfaction, body image, and hope in the relationship between appearance management behavior and happiness in 234 adults working in highway rest areas nationwide. Data analysis was performed using SPSS PC+ 25.0 and SPSS PROCESS macro3.5, and triple mediating effect analysis was performed using frequency analysis, reliability analysis, correlation analysis, and bootstrap analysis: This study was conducted to verify the triple mediating effect of appearance satisfaction, body image and hope in the relationship between appearance management behavior and happiness. The conclusions of the study are as follows. First, in the correlation analysis between the major variables, there were mostly significant positive correlations between appearance management behavior, appearance satisfaction, body image, hope, and happiness, but there was no correlation between body image and happiness or appearance satisfaction and happiness. Second, appearance management behavior had a significant positive effect on appearance satisfaction, appearance satisfaction had a significant positive effect on body image, body image had a significant positive effect on hope, and hope had a significant positive effect on happiness. Thus, appearance satisfaction, body image, and hope had a triple mediating effect in the relationship between appearance management behavior and happiness.
\end{abstract}

As described above, few studies have dealt with this precise issue, and the discussion of these relationships needs to be expanded. Our results imply that improving one's appearance through various behaviors in order to appear more beautiful to others leads to changes in appearance and increased satisfaction with appearance. Thus, appearance management behavior not only changes one's appearance, but also results in positive psychological changes. In the end, such changes may promote happiness. The results of this study can be used as a new model for happiness improvement through appearance management behavior in office workers.

Keywords Appearance Management Behavior, Appearance Satisfaction, Body Image, Hope, Happiness, Triple Mediating Effect

\section{Introduction}

Every person has a desire to be beautiful. While the concept of a beautiful appearance varies over time and in different countries, the methods and degrees of appearance management depend on the beauty standards of the society in the present era [1]. Management of one's outward appearance is achieved through certain behaviors, 
which scholars have named "appearance management behavior." Appearance management behavior involves improving one's appearance using clothes, makeup, accessories, and props to express oneself to others [2].

Making the appearance beautiful is an element of self-expression and individual competitiveness. In other words, the effort to make a good appearance becomes an opportunity to perceive and develop oneself anew, and provides information that can imprint oneself on others. As such, effort on appearance, that is, appearance management, is a process in which each individual performs self-expression while playing his/her role through mutual relationships with other people. Ali is a way of expression, and appearance management behavior is required to break free from the mental complex about one's physical flaws and appearance [3].

Appearance management behavior is known to be closely related to appearance satisfaction and body image. Appearance satisfaction is the degree to which one is satisfied with one's appearance, which also implies recognition of the effectiveness and competitiveness of one's appearance [4]. A body image is a mental image of one's body, and is greatly affected by one's attitudes and feelings toward the [5]. Naturally, satisfaction with appearance increases and a positive body image is formed when actions are taken that make one's appearance more beautiful. Appearance management behavior is important because appearance management can affect an individual not only externally but also internally.

Hope is a representative variable of positive psychology that is receiving a great deal of attention from scholars in various fields such as psychology, education, and welfare studies. Hope represents a positive motivational state of organized thinking through the interaction of successful pathways and initiatives [6]. Several studies have demonstrated that hope is a predictor of happiness, where happiness is both a subjective evaluation of one's life and also a subjective sense of well-being [7].

In this study, appearance satisfaction, body image, and hope were set as mediators in the relationship between appearance management behavior and happiness. Other studies have addressed the mediating roles of appearance satisfaction, body image, and hope, but it is difficult to find studies that simultaneously identify the roles of these variables. According to prior studies, appearance satisfaction is mediated by the relationship between depression and interpersonal propensity as well as that between self-efficacy and interpersonal propensity [8]; body image is mediated by the relationship and strength of communication between mother and child as well as the sense of happiness [9]; and there is a mediating effect of hope in the relationship between body image and successful aging [10].

Appearance management behavior reportedly has a positive relationship with appearance satisfaction and body image [11]. Also, hope and happiness have a positive relationship [12].

Considering these studies, appearance satisfaction, body image, and hope are predicted to play a mediating role in the relationship between appearance management behavior and happiness.

The reasons for selecting this research topic are as follows.

First, this study is necessary because Korea has become materially prosperous through rapid economic growth, but has a low sense of happiness. Korea ranks 29th out of 38 OECD countries in the 'Better Life Index' [13] and office workers are experiencing increasingly fierce competition, but research on 'workers' happiness' is still in its infancy [14]. It is necessary to investigate the relationship between the happiness of Korean workers and related variables.

Second, although the discussion on employee happiness is increasing, the scope is relatively limited. Most of the studies on the happiness of office workers are on leisure life [15] and psychological variables [16] the current situation. Also, based on the study that appearance management behavior affects happiness [17]. It is necessary to set the related variables as mediating variables to understand how the appearance management behavior of office workers affects happiness.

Therefore, the purpose of this study is to provide basic data that can be used to enhance the happiness of office workers by investigating the triple mediating effect of appearance satisfaction, body image, and hope in the relationship between appearance management behavior and happiness. The following research questions were used to achieve this goal.

First, what is the correlation between appearance management behavior, appearance satisfaction, body image, hope, and happiness?

Second, is there a triple mediating effect of appearance satisfaction, body image, and hope in the relationship between appearance management behavior and happiness?

\section{Materials and Methods}

\subsection{Research Model}

The research model was established by applying Hayes' PROCESS macro model 6 [18]. This triple mediation model is illustrated in Figure 1. 


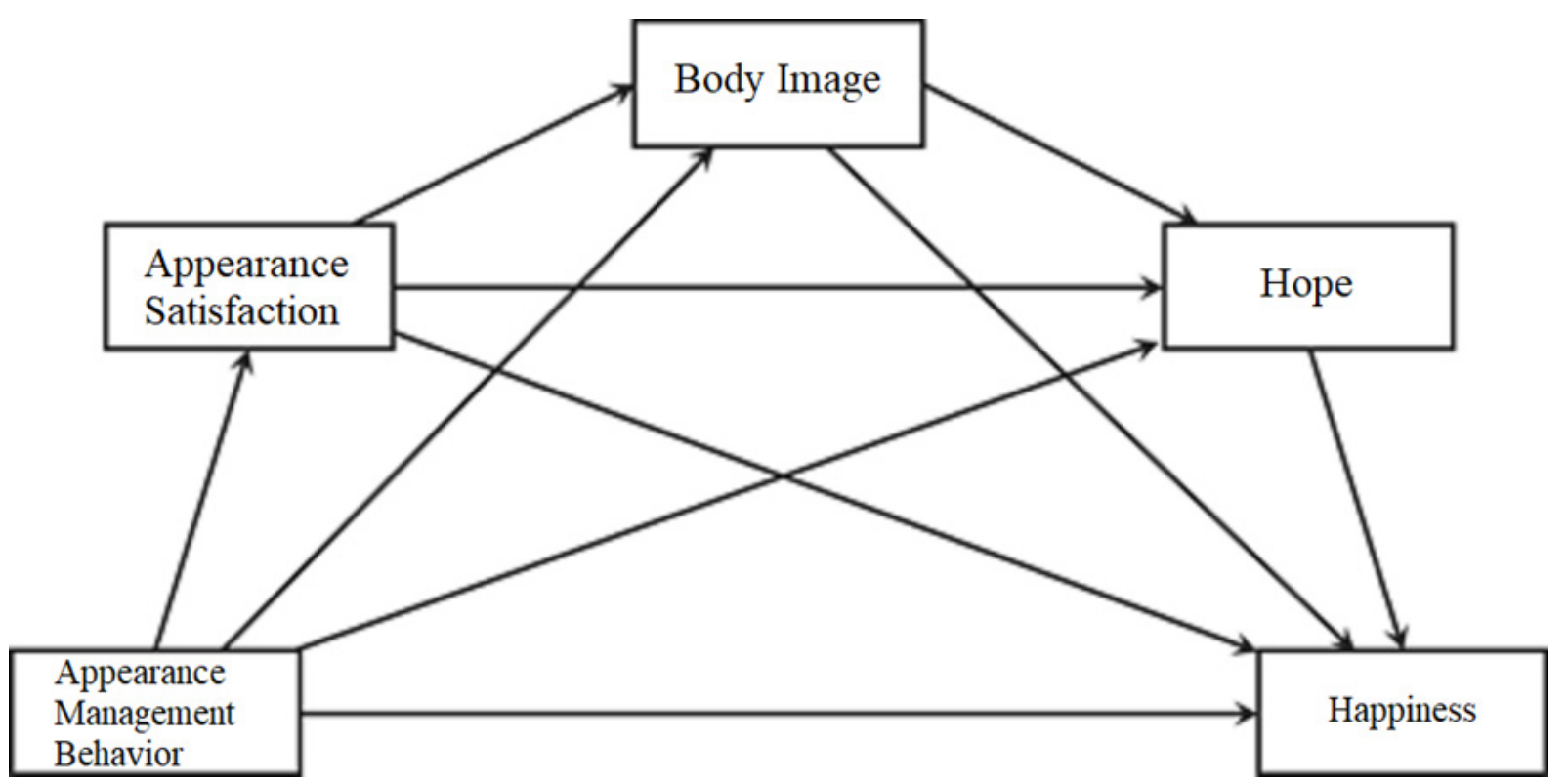

Figure 1. Research Model

\subsection{Research Subjects and Data Collection Method}

The subjects of this study were 250 adults working at highway rest areas across the country. There are a total of 22 highways in Korea, including the Gyeongbu Line and the West Coast Line, and there are a total of 205 service areas. Significant sampling was used for the sampling, and the purpose of the study was explained over the wire to 8 rest stops located on three highways between Gyeongbu Line, Jungbu Line, and Daegu-Pohang Expressway.

For the number of subjects required for this study, the effect size was set to .15 using the $G^{*}$ Power analysis program, the significance level was .05 , and the power was .95. As a result, the result was 172. However, considering the dropout rate, the number must be at least 190. The number of subjects used for analysis in this study was 234 , and a sufficient sample was secured.

For data collection, the researcher directly visits the service area where the researcher agreed to the survey over 3 months from October to December 2019, and fully explains the purpose, method, and voluntary participation and cessation of participation of the survey to the subject, and Only those who consented to this were distributed and collected the questionnaire.

The subjects of the survey included more women $(65.4 \%)$ than men $(34.6 \%)$, and the most frequent age group was over 50 (33.9\%). Most of the subjects were married (54.9\% vs. unmarried, $45.1 \%)$. The most frequent academic background, at more than half of all respondents, was high school graduation or less $(56.6 \%)$, and the most frequent income level was moderate (58.7\%).

\subsection{Survey Tools}

The survey tools used in this study consisted of appearance management behavior, appearance satisfaction, body image, hope, and sense of happiness, and the general items consisted of gender, age, marital status, education and income level.

The main variables are to be measured subjectively by the subject, because subjects with the same height and weight will have different evaluations. In particular, among the determinants of quality of life mixed with happiness, an individual's objective variable had an indirect effect, but the subjective variable had both an indirect effect and a direct influence relationship [19]. Therefore, in order to understand the role of related variables in the relationship between appearance management behavior and happiness, subjective measurements of the study subjects are required, and a measurement tool whose validity and reliability has been verified in previous studies is intended to be used.

\subsubsection{Appearance Management Behavior}

Appearance management behavior can be achieved through individual effort and can achieve self-satisfaction, and refers to an identity tool to make it appear as an ideal standard that one expects, not an indicator that distinguishes women from men [20]. The scales of Noh [21], Shin [22] and Kim et al. [23] as revised and supplemented by Lee [24] were used to measure appearance management behavior. Answers were provided using a 5-point Likert scale, and the reliability of appearance management behavior in this study had a Cronbach's $\alpha$ value of .840 , which was satisfactory.

\subsubsection{Appearance Satisfaction}

Appearance satisfaction refers to the degree of satisfaction with the appearance expressed by one's appearance and body decoration [25]. in this study Kim 
[26] and used by Park [27]. This is also a 5-point Likert scale, and the reliability of appearance satisfaction in this study had a Cronbach's $\alpha$ value of .869, which was high.

\subsubsection{Body Image}

Body image refers to the feeling that an individual has about his or her body type [28]. In this study, (Multidimensional Body-Self Relation Questionnaire) devised by Cash [29] and used Lee [24]. This is also a 5 -point Likert scale, and the reliability of body image in this study had a Cronbach's $\alpha$ value of .825 .

\subsubsection{Hope}

Hope is a positively motivated state of thought in which successful pathways and initiatives are interactively organized Snyder et al [30] and adapted Choi, Lee and Lee [31]. This scale consists of a total of 8 questions comprising 4 questions on pathway thinking and 4 questions on agency thinking. It is a 5-point Likert scale, and the reliability of hope in this study had a Cronbach's $\alpha$ value of .825 .

\subsubsection{Happiness}

Happiness refers to a pleasant emotional state experienced by humans and a subjective state of being satisfied with one's life [32] and in this study Suh and Koo [33]. This scale consists of 3 questions about life satisfaction and 6 questions about feelings experienced by the respondents over the course of a month. The answers were provided on a 7-point Likert scale. In this study, the reliability of happiness had a Cronbach's $\alpha$ value of .866 .

\section{Results}

\subsection{Correlation and Descriptive Statistics}

Any Pearson's correlation analysis was performed to identify the correlations between major variables. The results are shown in Table 1.

There was a significant positive correlation between appearance management behavior, appearance satisfaction, body image, hope, and happiness, but there was no correlation between body image and happiness or appearance satisfaction and happiness.

Specifically, the relationship between appearance satisfaction and body image had the highest correlation coefficient $(\mathrm{r}=.620, p<.01)$, followed by that between hope and body image $(\mathrm{r}=.486, p<.01)$, then hope and appearance satisfaction $(\mathrm{r}=.428, p<.01)$.

Descriptive statistics analysis showed that the average scores of hope $(M=3.3607)$, body image $(M=3.0975)$, and appearance management behavior $(\mathrm{M}=3.0559)$ exceeded the median value, whereas the average scores of appearance satisfaction $(\mathrm{M}=2.9644)$ and happiness $(\mathrm{M}=$ 3.9971) did not exceed the median value.

\subsection{Investigation of the Triple Mediating Effect}

The PROCESS macro 6 model proposed by Hayes [18] was used to investigate the triple mediating effect of appearance satisfaction, body image and Hope in the relationship between appearance management behavior and happiness. The results are presented in Table 2 and Figure 2.

Table 1. Results of Correlation Analysis and Descriptive Statistics Analysis

\begin{tabular}{|c|c|c|c|c|c|c|c|}
\hline Division & $\begin{array}{c}\text { Appearance } \\
\text { Management } \\
\text { Behavior }\end{array}$ & $\begin{array}{l}\text { Appearance } \\
\text { Satisfaction }\end{array}$ & $\begin{array}{l}\text { Body } \\
\text { Image }\end{array}$ & Hope & Happiness & M & SD \\
\hline $\begin{array}{c}\text { Appearance } \\
\text { Management } \\
\text { Behavior } \\
\end{array}$ & 1 & & & & & 3.0559 & .54145 \\
\hline $\begin{array}{l}\text { Appearance } \\
\text { Satisfaction }\end{array}$ & $.336^{* *}$ & 1 & & & & 2.9644 & .67225 \\
\hline Body Image & $.337^{* *}$ & $.620^{* *}$ & 1 & & & 3.0975 & .60103 \\
\hline Hope & $.371^{* *}$ & $.428^{* *}$ & $.486^{* *}$ & 1 & & 3.3607 & .65099 \\
\hline Happiness & $.132^{*}$ & .073 & .123 & $.293^{* *}$ & 1 & 3.9971 & 1.21365 \\
\hline
\end{tabular}


Table 2. Triple Mediating Effect of Appearance Satisfaction, Body Image and Hope on Happiness

\begin{tabular}{|c|c|c|c|c|c|c|}
\hline Variable & coeffect & se & $\mathbf{t}$ & $p$ & LLCI $^{*}$ & $\mathbf{U L C I}^{* *}$ \\
\hline \multicolumn{7}{|c|}{ Mediating variable model (Dependent Variable: Appearance Satisfaction) } \\
\hline Constant & 1.7828 & .2466 & 7.2296 & .0000 & 1.2968 & 2.2688 \\
\hline $\begin{array}{c}\text { Appearance } \\
\text { Management } \\
\text { Behavior }\end{array}$ & .3934 & .0790 & 4.9777 & .0000 & .2376 & .5492 \\
\hline \multicolumn{7}{|c|}{ Mediating variable model (Dependent variable: Body Image) } \\
\hline Constant & 1.1298 & .2017 & 5.6021 & .0000 & .7323 & 1.5273 \\
\hline $\begin{array}{c}\text { Appearance } \\
\text { Management } \\
\text { Behavior }\end{array}$ & .1594 & .0613 & 2.6016 & .0099 & .0387 & .2802 \\
\hline $\begin{array}{l}\text { Appearance } \\
\text { Satisfaction }\end{array}$ & .5007 & .0496 & 10.1014 & .0000 & .4030 & .5983 \\
\hline \multicolumn{7}{|c|}{ Mediating variable model (Dependent variable: Hope) } \\
\hline Constant & 1.0689 & .2576 & 4.1496 & .0000 & .5612 & 1.5767 \\
\hline $\begin{array}{c}\text { Appearance } \\
\text { Management } \\
\text { Behavior }\end{array}$ & .2527 & .0743 & 3.3994 & .0008 & .1062 & .3992 \\
\hline $\begin{array}{l}\text { Appearance } \\
\text { Satisfaction }\end{array}$ & .1517 & .0717 & 2.1161 & .0355 & .0104 & .2930 \\
\hline Body Image & .3465 & .0807 & 4.2931 & .0000 & .1875 & .5056 \\
\hline \multicolumn{7}{|c|}{ Dependent variable model (Dependent variable: Happiness) } \\
\hline Constant & 2.1332 & .5589 & 3.8168 & .0002 & 1.0317 & 3.2348 \\
\hline $\begin{array}{c}\text { Appearance } \\
\text { Management } \\
\text { Behavior }\end{array}$ & .1036 & .1593 & .6501 & .5163 & -.2104 & .4176 \\
\hline $\begin{array}{l}\text { Appearance } \\
\text { Satisfaction }\end{array}$ & -.1296 & .1513 & -.8566 & .3926 & -.4277 & .1686 \\
\hline Body Image & .0150 & .1756 & .0857 & .9318 & -.3310 & .3611 \\
\hline Hope & .5608 & .1415 & 3.9641 & .0001 & .2820 & .8396 \\
\hline \multicolumn{7}{|c|}{ Total effect, Direct effect } \\
\hline Division & Effect & se & $\mathrm{t}$ & $\mathrm{p}$ & LLCI $^{*}$ & $\mathrm{ULCI}^{* *}$ \\
\hline Total effect & .3024 & .1497 & 2.0205 & .0445 & .0074 & .5974 \\
\hline Direct effect & .1036 & .1593 & .6501 & .5163 & -.2104 & .4176 \\
\hline
\end{tabular}

* $\overline{L L C I}=$ Lower limit within $95 \%$ confidence interval of boot indirect effect

**ULCI $=$ Upper limit within $95 \%$ confidence interval of boot indirect effect 


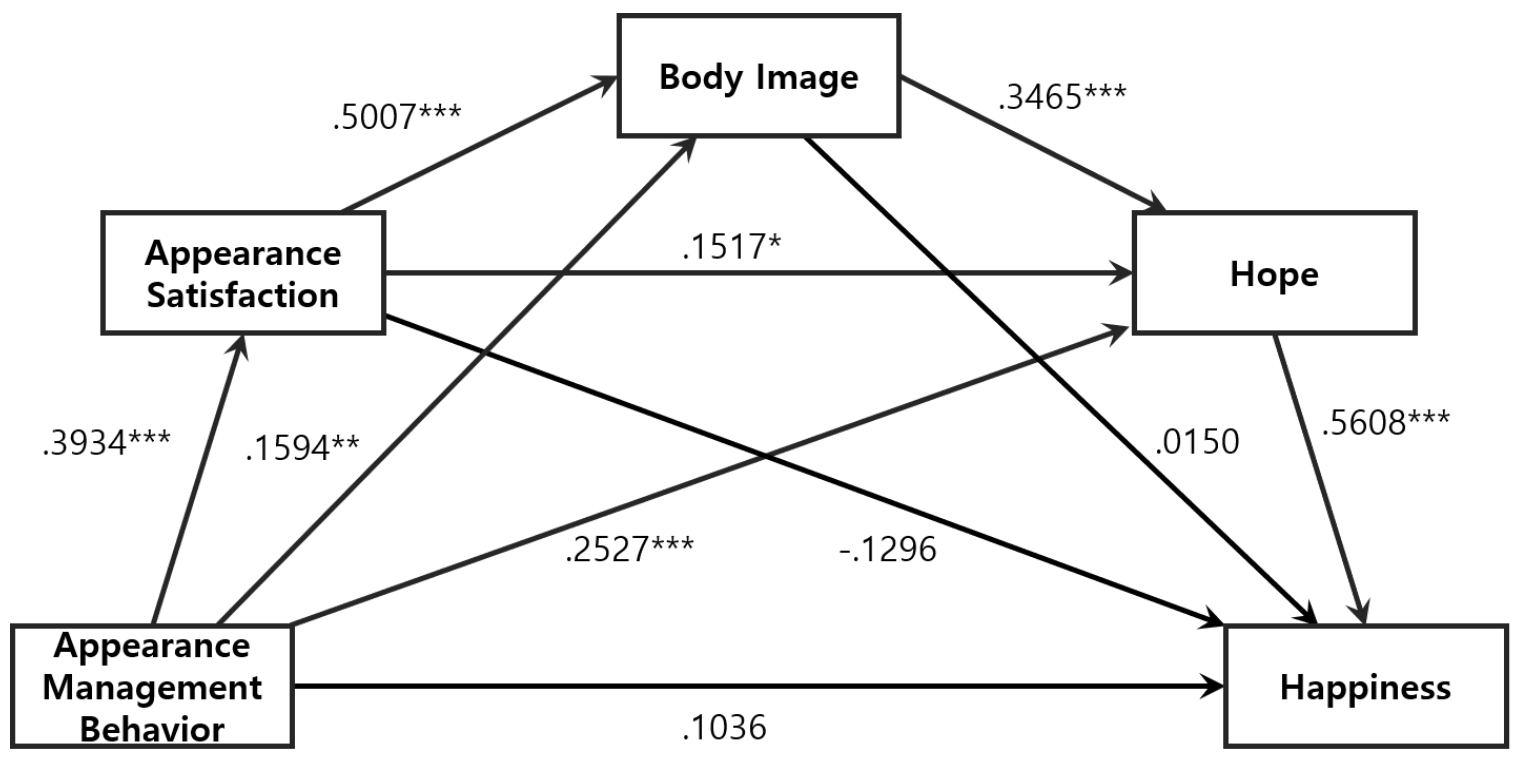

Figure 2. The values of each path

The analysis showed that appearance management behavior, an independent variable, had a significant positive effect on appearance satisfaction $(.3934, p<.001)$, a significant positive effect on body image $(.1594, p<.01)$ and a significant positive effect on hope $(.2527, p<.001)$. However, it did not affect happiness, the dependent variable $(.1036, p>.05)$.

In addition, appearance satisfaction had a significant positive effect on body image $(.5007, p<.001)$ and a significant positive effect on hope $(.1517, p<.05)$, but no effect on happiness $(-.1296, p>.05)$.

Body image had a significant positive effect on hope $(.3465, p<.001)$ but no effect on happiness $(.0150$, $p>.05)$. Hope had a significant positive effect on happiness $(.5608, p<.001)$.

Meanwhile, the total effect of happiness on appearance management behavior was $.3024(p<.05)$, and when the mediating variables of appearance satisfaction, body image and Hope were introduced, the direct effect of happiness on appearance management behavior was no longer significant $(p>.05)$.
To summarize, appearance management behavior affects appearance satisfaction, which affects body image, while body image has a significant effect on hope, and hope has a significant effect on happiness. Furthermore, although the total effect of the pathway between appearance management behavior and happiness was significant, the significance of the direct effect disappeared as the mediating variables were introduced. These findings show that there is a mediating effect between these variables. Therefore, in this study, the indirect effects of appearance satisfaction, body image, and hope were verified

Table 3 shows the bootstrap analysis results of the indirect effects of appearance satisfaction, body image and Hope. The indirect effects were significant in 3 out of a total of 7 pathways. Among them, in the pathway of appearance management behavior $\rightarrow$ appearance satisfaction $\rightarrow$ body image $\rightarrow$ hope $\rightarrow$ happiness, the indirect effects were verified, as the upper and lower limits of the bootstrap did not contain " 0 " $(.0383, .0092-.0854)$ 
Table 3. Indirect Effects of Body Image, Appearance Satisfaction and Hope on Happiness

\begin{tabular}{|c|c|c|c|c|}
\hline \multicolumn{5}{|c|}{ Indirect effect } \\
\hline Pathway & Effect & Boot SE & BootLLCI & BootULCI \\
\hline Total & .1988 & .0893 & .0338 & .3830 \\
\hline $\begin{array}{l}\text { Ind1: Appearance Management Behavior } \rightarrow \text { Appearance Satisfaction } \\
\rightarrow \text { Happiness }\end{array}$ & -.0510 & .0626 & -.1853 & .0678 \\
\hline Ind2: Appearance Management Behavior $\rightarrow$ Body Image $\rightarrow$ Happiness & .0024 & .0289 & -.0573 & .0614 \\
\hline Ind3: Appearance Management Behavior $\rightarrow$ Hope $\rightarrow$ Happiness & .1417 & .0573 & .0404 & .2663 \\
\hline $\begin{array}{l}\text { Ind4: Appearance Management Behavior } \rightarrow \text { Appearance Satisfaction } \\
\rightarrow \text { Body Image } \rightarrow \text { Happiness }\end{array}$ & .0030 & .0349 & -.0636 & .0777 \\
\hline $\begin{array}{l}\text { Ind5: Appearance Management Behavior } \rightarrow \text { Appearance Satisfaction } \\
\rightarrow \text { Hope } \rightarrow \text { Happiness }\end{array}$ & .0335 & .0228 & -.0030 & .0848 \\
\hline $\begin{array}{l}\text { Ind6: Appearance Management Behavior } \rightarrow \text { Body Image } \rightarrow \text { Hope } \rightarrow \\
\text { Happiness }\end{array}$ & .0310 & .0188 & .0016 & .0735 \\
\hline $\begin{array}{l}\text { Ind7: Appearance Management Behavior } \rightarrow \text { Appearance Satisfaction } \\
\rightarrow \text { Body Image } \rightarrow \text { Hope } \rightarrow \text { Happiness }\end{array}$ & .0383 & .0198 & .0092 & .0854 \\
\hline
\end{tabular}

\section{Suggestions}

This study was conducted to verify the triple mediating effect of appearance satisfaction, body image and hope in the relationship between appearance management behavior and happiness. The conclusions of the study are as follows.

First, as a result of correlation analysis between major variables, there were mostly significant positive correlations between appearance management behavior, appearance satisfaction, body image, hope and happiness, but there was no correlation between body image and happiness, and appearance satisfaction and happiness. This result showed a positive relationship between appearance management behavior, appearance satisfaction, and body image [11], and it is consistent with the report that hope and happiness have a significant positive relationship [12].

Second, appearance management behavior had a significant positive effect on appearance satisfaction, which had a significant positive effect on body image, while body image had a significant positive effect on hope, and hope had a significant positive effect on happiness. Thus, appearance satisfaction, body image, and hope had a triple mediating effect in the relationship between appearance management behavior and happiness. As described above, few studies have dealt with this precise issue, and the discussion of these relationships needs to be expanded. Our results imply that improving one's appearance through various behaviors in order to appear more beautiful to others leads to changes in appearance and increased satisfaction with appearance. Thus, appearance management behavior not only changes one's appearance, but also results in positive psychological changes. In the end, such changes may promote happiness.

\section{Conclusions}

The limitations of this study and suggestions for subsequent studies are as follows.

First, this study verified the triple mediating effect of appearance satisfaction, body image and hope. However, the subjects of the study were limited to workers employed at highway rest areas. Therefore, it is necessary to study whether the same triple mediating effect applies to subjects in various occupational groups and regions.

Second, in this study, while appearance management behavior was shown to affect happiness, a model that illustrates the mediating effects of appearance satisfaction, body image, and hope was verified. Accordingly, it would be beneficial to develop an educational program on appearance management as a way to improve the happiness of office workers.

Third, this study verified the mediating effects of appearance satisfaction, body image, and hope, but did not deal with the moderating effect. Therefore, in follow-up studies, it is necessary to investigate whether the effect of appearance management behavior on happiness changes in size or direction by any variable

Despite these limitations, this study is meaningful in that hope, which is a representative variable of positive psychology, which has hardly been dealt with in cosmetology, was input as a mediating variable, and that appearance management behavior brings external and internal changes, leading to happiness.

The results of this study will be used as a new happiness promotion model that utilizes the appearance management behavior of office workers in academia, and in the field, it can be developed into an educational program that can be practiced on its own, such as appearance change, makeup, and skin care to promote employees' happiness. Furthermore, at the organizational 
level, it is predicted that the enhancement of the happiness of members will contribute to the formation of a positive organizational culture.

\section{REFERENCES}

[1] P. Rozin, A. Fallon., "Body image", attitudes to weight, and misperceptions of figure preferences of the opposite sex", a comparison of men and women in two generations. Journal of abnormal psychology, vol. 97, no. 3, pp. 342, 1988. DOI: 10.1037/0021-843X.97.3.342

[2] E. Goffman., "Ordre Social Et L'interaction”, 1991. doi.org/10.2307/202090

[3] Kaiser, C. A., \& Schekman, R. Distinct sets of SEC genes govern transport vesicle formation and fusion early in the secretory pathway. Cell, 61(4), 723-733, 1990. DOI: https://doi.org/10.1016/0092-8674(90)90483-U

[4] M. H. Choi., "Analysis of the relationship between parenting attitudes, irrational beliefs, and appearance satisfaction perceived by college students", Konkuk University Graduate School, Master's Thesis. 2006.

[5] T. F. Cash., T. Pruzinsky., "Future challenges for body image theory, research, and clinical practice. Body image", A handbook of theory, research, and clinical practice, pp. 509-516, 2002. DOI: 10.1080/10640260290081678

[6] C. R. Snyder, L. M. Irving, J. R. Anderson., "Hope and health. Handbook", of social and clinical psychology: The health perspective, vol. 162, pp. 285-305, 1991. https://scholarship.richmond.edu/bookshelf

[7] M. L. Diener, M. B. Diener McGavran., "What makes people happy?", A developmental approach to the literature on family relationships and well-being. In M. Eid \& R. J. Larsen (Eds.), The science of subjective well-being, pp. 347-375. Guilford Press, 2008. DOI: 10.1037/0893-3200.1 0.1 .60

[8] K. H. Lee, E.R. Bang., "The Analysis of Effects of University Students' Depression and Self-Efficiency on the Trends of Personal Relationship", Korean Comparative Government Review, vol. 15, no. 1, pp. 325-348, 2011 DOI: 10.18397/kcgr.2011.15.1.325

[9] T. S. Kim., "The Effects of Father- and Mother-Adolescent Communications on Adolescent Happiness", The Mediating Role of Body Image. Youth Studies vol. 24, no. 10, pp. 107-138, 2017. DOI: 10.21509/KJYS.2017.10.24.1 0.107

[10] Y. K. Hwang, C.S. Lee., "The Dual Mediating Effects of Growth mindset and Hope in the Relationship between Body Image and Successful Aging of the Elderly", Journal of Industrial Convergence, vol. 18, no. 1, pp.87-96, 2020. DOI: 10.22678/JIC.2020.18.1.087

[11] S. J. Woo, E. H. Lee., "The Effects of Male University Students' Body Management Behaviors and Body Image Perception on Appearance Satisfaction", Journal of the Korean Beauty Art Society, vol. 8, no. 3, pp. 32-42, 2014. http://www.riss.kr.library.hanseo.ac.kr:8000/link?id=T137
35970

[12] H. I. Hwang, H. M. Kang, J. H. Tak., "The structural relations among pre-service teachers' happiness, optimism, hope and emotion affectivity", Korean Early Childhood Education Association, vol. 35, no. 3, pp. 365-386, 2015. DOI: $10.18023 / \mathrm{kjece} .2015 .35 .3 .016$

[13] Better Life Index of OECD and Korea Ranking, 2017. https://stats.oecd.org

[14] Fisher, E., "Media and new capitalism in the digital age" The spirit of networks. Springer, 2010.

[15] Y. J. Nam, S. J. Oh, E. H. Kim, S. G. Nam., "The effect of stress and leisure activities on satisfaction and happiness of office workers" Journal of Arts, Humanities and Social Convergence Multimedia, vol. 8, no. 4, pp. 883-891, 2018. DOI: 10.35873 /ajmahs.2018.8.4.080

[16] H. K. Lee, C. Y. Nam., "The effect of job stress, depression, and psychological well-being of office workers on job satisfaction" Journal of the Korean Society for Nursing Education, vol. 21, no. 4, pp. 489-497, 2015. DOI: 10.5977/Jkasng.2015.21.4.490

[17] S. J. Park, K. H. Kim., "The effect of women's appearance management behavior on psychological well-being and self-efficacy" Fashion and knitwear, vol. 17, no. 1, pp. 35-46, 2019. http://www.riss.kr/link?id=A106065290

[18] A. F. Hayes., "Introduction to mediation, moderation, and conditional process analysis", A regression-based approach. Guilford publications, 2017.

[19] S. T. Han., "A study on the determinants of quality of life in the elderly: Comparison of objective and subjective variables" Korean Journal of Public Administration, vol. 42, no. 3, pp. 441-461, 2008. http://www.riss.kr/link?id=A104 7263

[20] Goffman, E., "The moral career of the mental patient. Psychiatry, vol. 22, no. 2, pp. 123-142, 1959. doi.org/10.1080/00332747.1959.11023166

[21] J. Y. Noh., "A Study on Development of Fashion Orientation Scale for the On-line Image Consulting of Career Men", Society, Journal of the Korean Society for Clothing Industry, vol. 9, no. 1, pp. 58 67, 2005. http://www.riss.kr.library.hanseo.ac.kr:8000/link?id=T802 2809

[22] Y. W. Shin., "A study on the influencing factors of male appearance management behavior", Yonsei University Graduate School Master's Thesis. 2006. http://www.riss.kr.library.hanseo.ac.kr:8000/link?id=T105 05240

[23] Y. H. Kim, M. J. Kim, J. S. Hwang., "The effect of mass media on fashion leadership of make-up and fashion products", Journal of the Korean Society of Clothing and Textiles, vol. 30, no. 2, pp. 266-274, 2006. http://www.riss.kr.library.hanseo.ac.kr:8000/link?id=T106 64192

[24] H. J. Lee., "Differences in career openness, career exploration, and career identity by sex and level of social anxiety", Korean Journal of Educational Research, vol. 46, no. 1, pp. 79-99, 2008.http://www.riss.kr.library.hanseo.ac 
$. \mathrm{kr}: 8000 / \mathrm{link} ? \mathrm{id}=\mathrm{A} 104845033$

[25] Young, D. A., Wiersema, R. J., \& Hawthorne, M. F. (1971). Alkylaluminum and alkylgallium derivatives of (3)-1, 2-B9C2H13. Journal of the American Chemical Society, 93(22), 5687-5694.

[26] M. Y. Kim., "A Study on the Autonomy of School Uniforms and Appearance Satisfaction for Female Middle and High School Students", Sangmyung Women's University graduate school master's thesis, 1984. http://www.riss.kr.library.hanseo.ac.kr:8000/link?id=T371 7445

[27] H. W. Park., "The Influences of Self-Assertiveness, Appearance Management Behavior and Appearance Satisfaction on Psychological Well-Being", Chonnam National University doctoral dissertation, 2013. http:/ /www.riss.kr/link?id=T13036849

[28] Price, S. R., \& Price, S. R. Rituals and power: the Roman imperial cult in Asia Minor, Cambridge University Press, 1986.

[29] T. A. Brown, T. F. Cash., P. J. Mikulka., "Attitudinal body-image assessment: Factor analysis of the Body-Self
Relations Questionnaire" Journal of personality assessment, vol. 55, no. $1-2$, pp. 135-144. 1990. DOI: $10.1080 / 00223891.1990 .9674053$

[30] Snyder, C. R., Irving, L. M., \& Anderson, J. R. Hope and health. Handbook of social and clinical psychology: The health perspective, 162, 285-305, 1991.

[31] Y. H. Choi, H. K. Lee, D. G. Lee., "A study on the validity of Snyder's Korean translation of the Hope Scale" Journal of the Korean Psychological Association: Society and Personality, vol. 22, no. 2, pp. 1-16, 2008. DOI: $10.26736 /$ sacore 2020

[32] Ryan, R. M., \& Deci, E. L. On happiness and human potentials: A review of research on hedonic and eudaimonic well-being. Annual review of psychology, 52(1), 141-166, 2001. doi.org/10.1146/annurev.psych.52.1.141

[33] E.K. Suh, J. S. Koo., “A Concise Measure of Subjective Well-Being COMOSWB): Scale Development and Validation", The Korean Journal of Social And Personality Psychology, vol. 25, no. 1, pp. 96-114. 2011. http://www.riss.kr.library.hanseo.ac.kr:8000/link?id=A104 030381 